Supporting Information

\title{
Boosting electrochemical performance of spinel cathode with the in-situ transformed allogenic Li-rich layered phase
}

Shenghua Yuan ${ }^{a}$, Jian $G u{ }^{b}$, Yue Ma, ${ }^{a}$ Hongzhou Zhang, ${ }^{a}{ }^{*}$ Dawei Song, ${ }^{a}$ Xixi Shi, ${ }^{a}$ and Lianqi Zhang, ${ }^{a,}$

${ }^{\mathrm{a}}$ Key Laboratory of Display Materials and Photoelectric Devices (MOE), School of Materials Science and Engineering, Tianjin University of Technology, 391 Binshui Road, Tianjin 300384, China.

${ }^{\text {b} T i a n j i n ~ E V ~ E n e r g i e s ~ C o ., ~ L t d . ~ N o .11, ~ K a i y u a n ~ R o a d, ~ X i q i n g ~ A u t o m o b i l e ~ I n d u s t r y ~}$ Park, Tianjin, 300380, China.

\section{Corresponding Author}

*E-mail: zhanghongzhou@mail.nankai.edu.cn (Hongzhou Zhang)

*E-mail: tianjinzhanglq@163.com (Lianqi Zhang)

Page S-3: Figure S1. Particle size distribution and SEM image of $\mathrm{Ni}_{0.2} \mathrm{Co}_{0.1} \mathrm{Mn}_{0.7} \mathrm{CO}_{3}$.

Page S-3: Figure S2. Initial charge-discharge curve of S-L-0.1 sample in the voltage range of $2-4.95 \mathrm{~V}$ at $800{ }^{\circ} \mathrm{C}, 850{ }^{\circ} \mathrm{C}$ and $900{ }^{\circ} \mathrm{C}$.

Page S-4: Figure S3. Initial charge-discharge curve and cycling performance of S800, S850 and S900 samples in the voltage range of $3.5-4.95 \mathrm{~V}$.

Page S-5: Figure S4. Different charge-discharge curves in the cycle process and cycling performance of S800, S850 and S900 samples in the voltage range of $2-3.5$ 
Page S-6: Figure S5. Initial charge-discharge curve and cycling performance of S850 and spinel@Li-rich samples in the voltage range of 3.5-4.95 V.

Page S-7: Figure S6. Initial charge-discharge curve and cycling performance of S850 and spinel@Li-rich samples in the voltage range of 2-3.5 V.

Page S-8: Figure S7. Initial charge-discharge curve of $\mathrm{Li}_{1.2} \mathrm{Ni}_{0.16} \mathrm{Co}_{0.08} \mathrm{Mn}_{0.56} \mathrm{O}_{2}$ sample at $0.1 \mathrm{C}$.

Page S-8: Figure S8. Equivalent circuit diagram of EIS impedance spectrum.

Page S-9: Table S1. EDX data of $\mathrm{Ni}_{0.2} \mathrm{Co}_{0.1} \mathrm{Mn}_{0.7} \mathrm{CO}_{3}$ sample. The amounts of metal cations are normalized by defining $\mathrm{Co}=1$.

Page S-9: Table S2. Lattice parameters and X-ray Rietveld refined patterns analysis of spinel sample.

Page S-9: Table S3. Electrochemical performance of spinel samples in the voltage range of $2.0-4.95 \mathrm{~V}$.

Page S-10: Table S4. Electrochemical performance of spinel and S-L samples in the voltage range of $2.0-4.95 \mathrm{~V}$.

Page S-10: Table S5. Impedance data of S sample and S-L-0.4 sample before and after 50 cycles. 

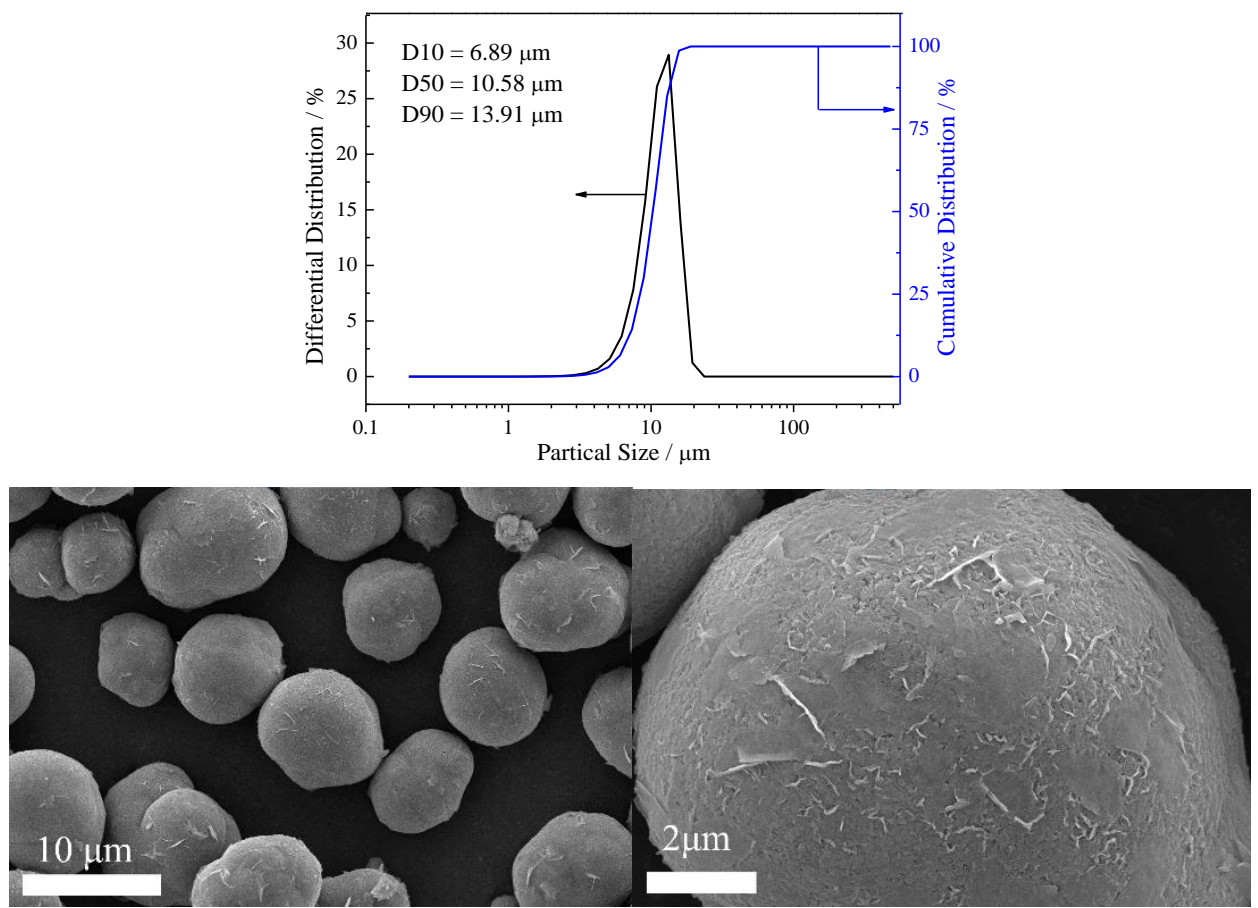

Figure S1. Particle size distribution and SEM image of $\mathrm{Ni}_{0.2} \mathrm{Co}_{0.1} \mathrm{Mn}_{0.7} \mathrm{CO}_{3}$.

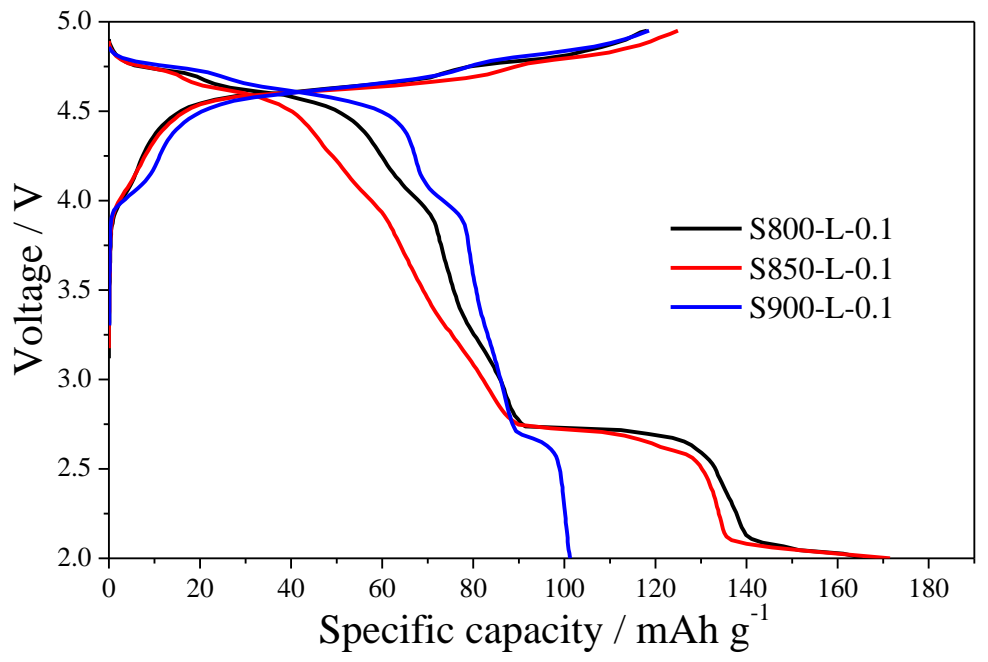

Figure S2. Initial charge-discharge curve of S-L-0.1 sample in the voltage range of 2 $-4.95 \mathrm{~V}$ at $800{ }^{\circ} \mathrm{C}, 850{ }^{\circ} \mathrm{C}$ and $900{ }^{\circ} \mathrm{C}$. 

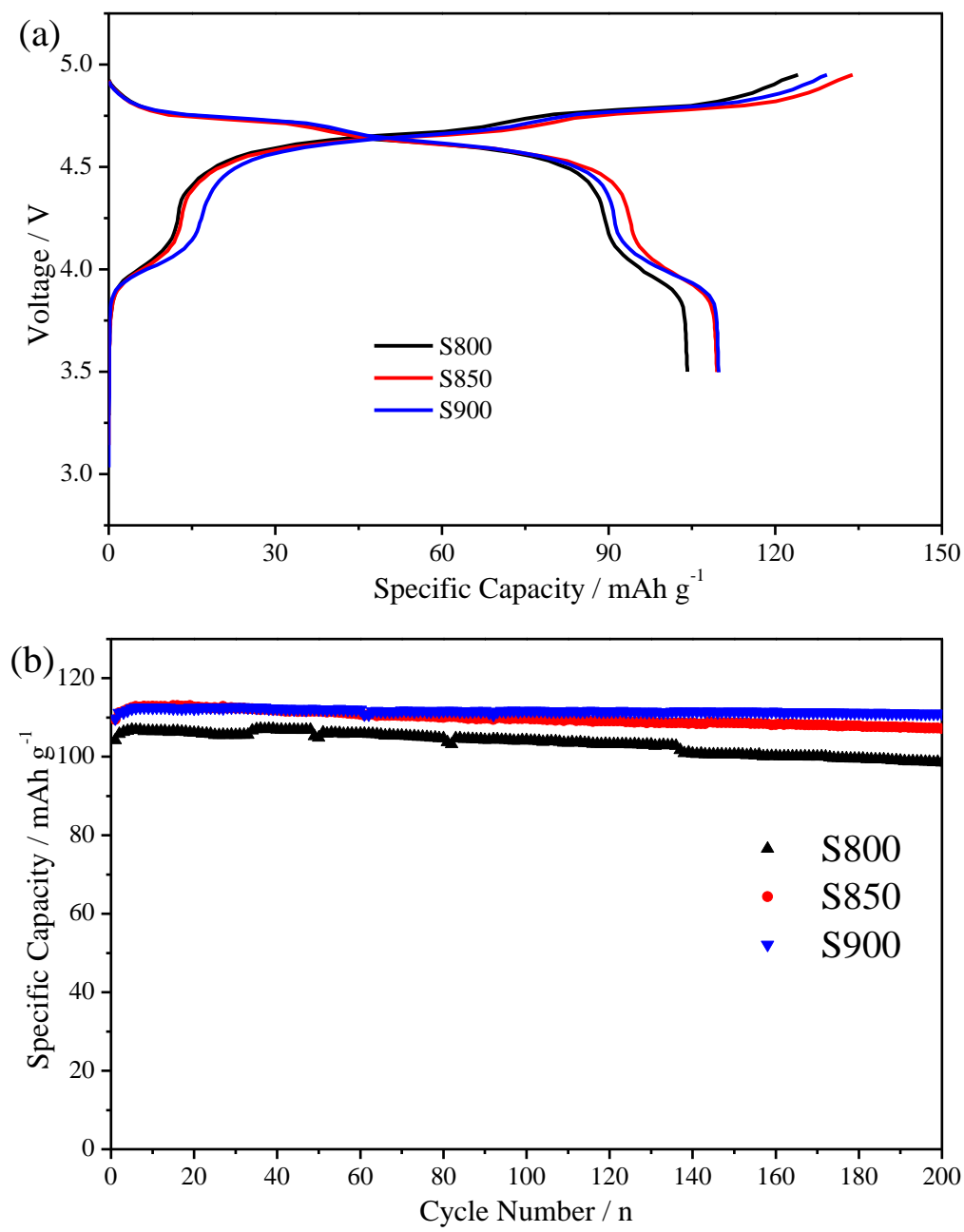

Figure S3. (a) Initial charge-discharge curve and (b) cycling performance of S800, S850 and S900 samples in the voltage range of $3.5-4.95 \mathrm{~V}$. 

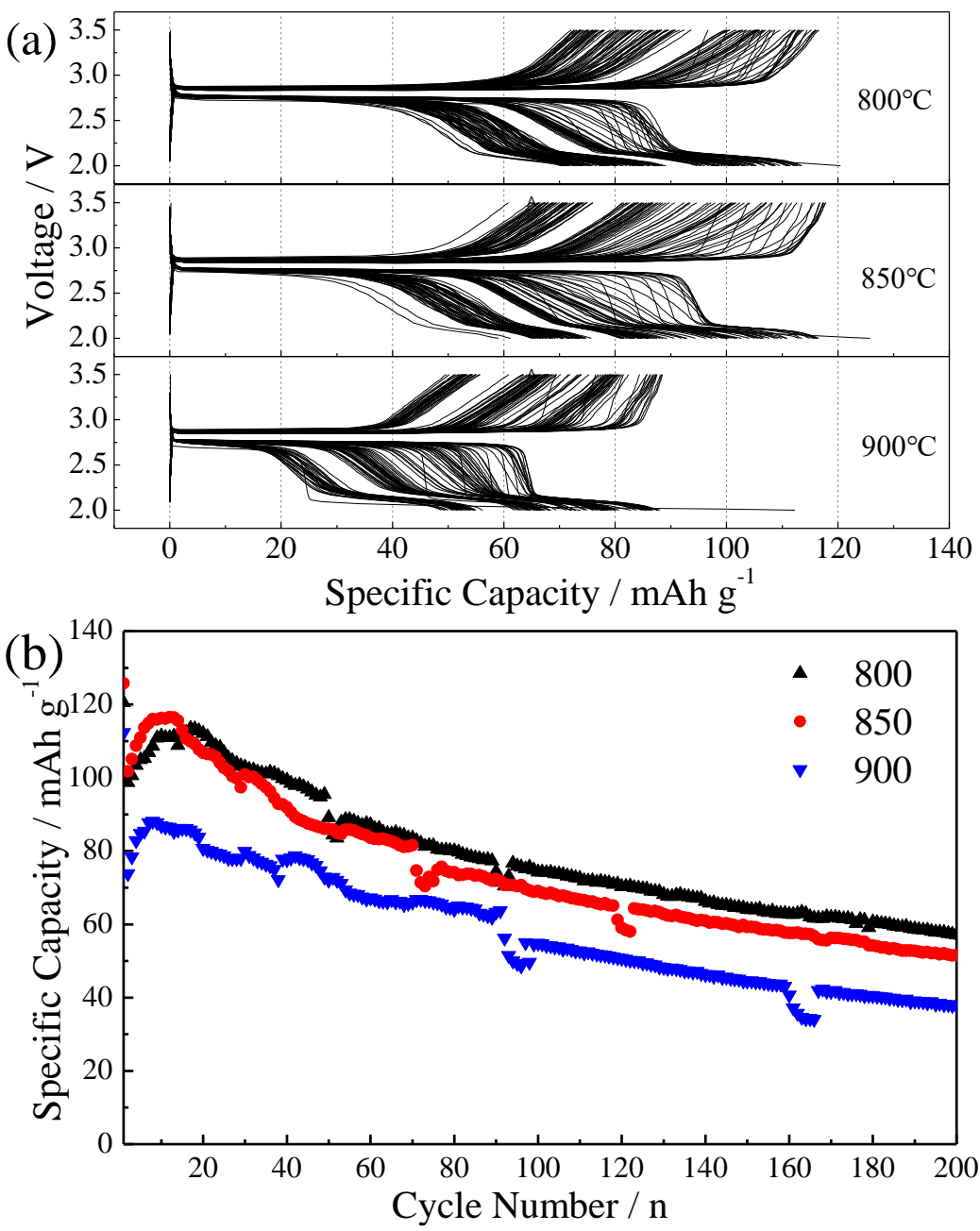

Figure S4. (a) Different charge-discharge curves in the cycle process and (b) cycling performance of S800, S850 and S900 samples in the voltage range of $2-3.5 \mathrm{~V}$. 

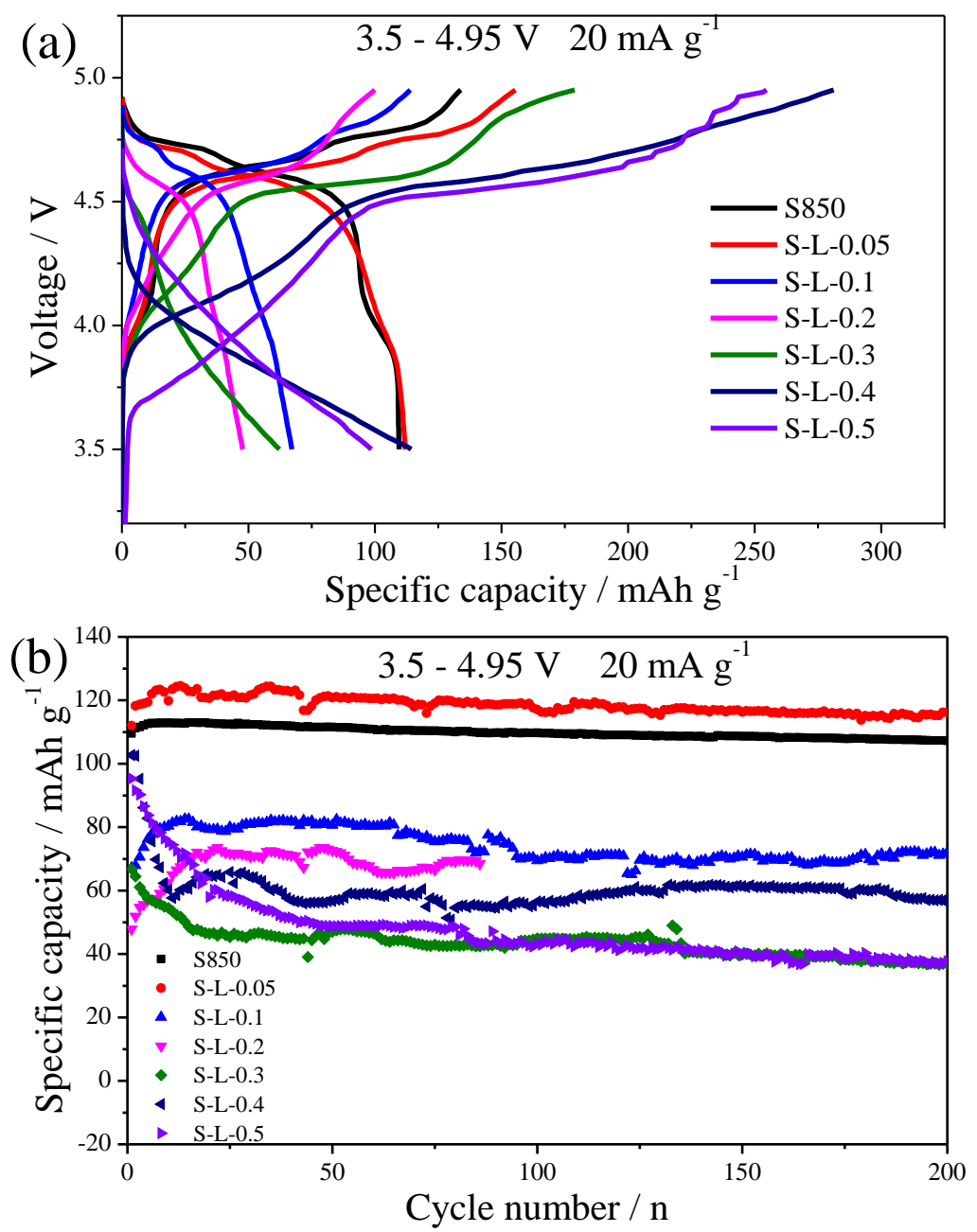

Figure S5. (a) Initial charge-discharge curve and (b) cycling performance of S850 and spinel@Li-rich samples in the voltage range of $3.5-4.95 \mathrm{~V}$. 

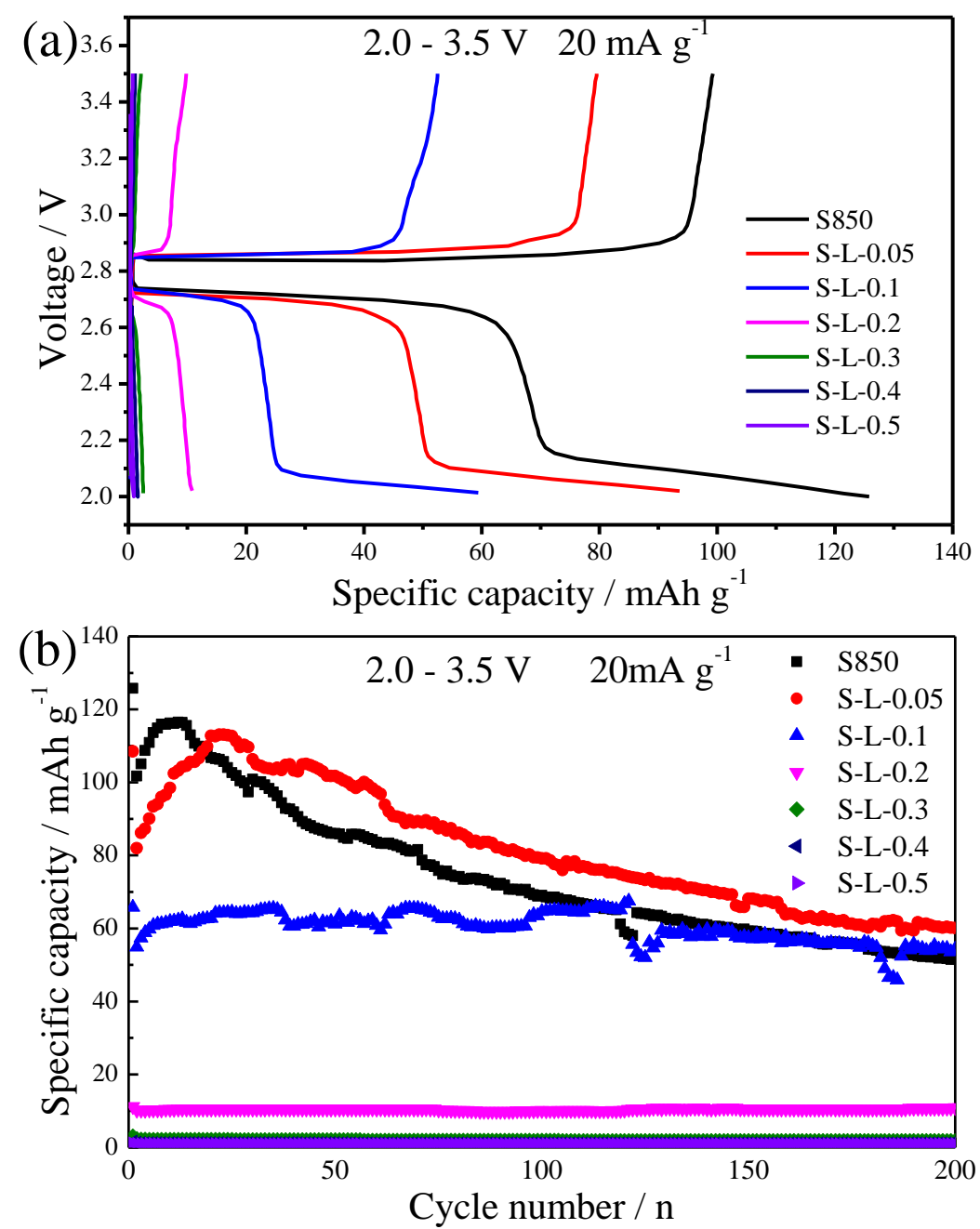

Figure S6. (a) Initial charge-discharge curve and (b) cycling performance of S850 and spinel@Li-rich samples in the voltage range of $2-3.5 \mathrm{~V}$. 


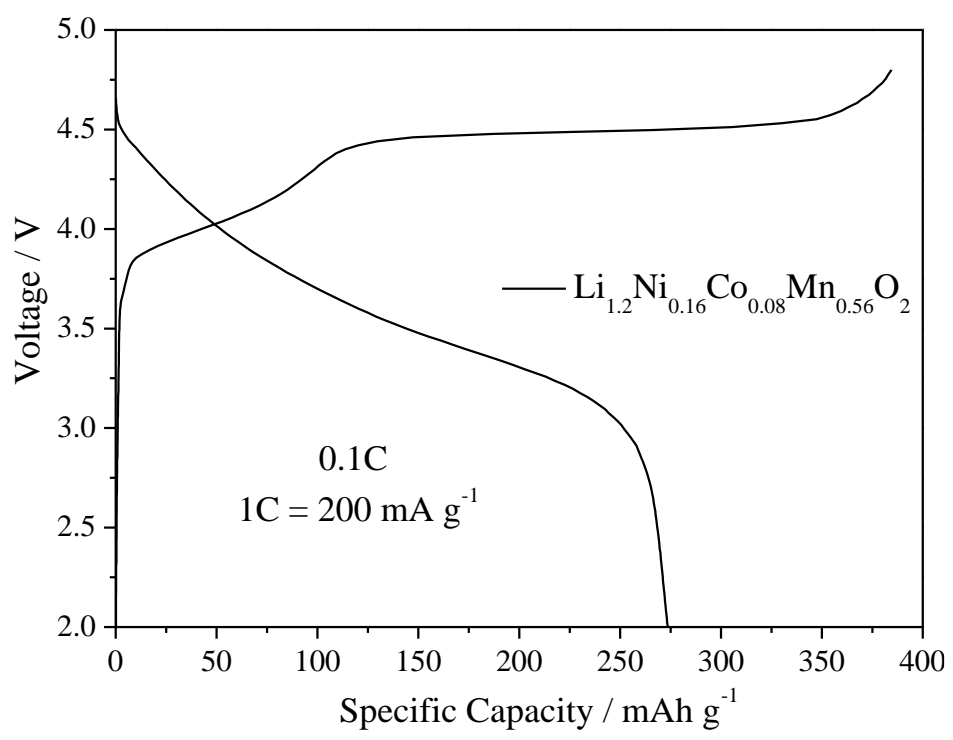

Figure S7. Initial charge-discharge curve of $\mathrm{Li}_{1.2} \mathrm{Ni}_{0.16} \mathrm{Co}_{0.08} \mathrm{Mn}_{0.56} \mathrm{O}_{2}$ sample at $0.1 \mathrm{C}$.

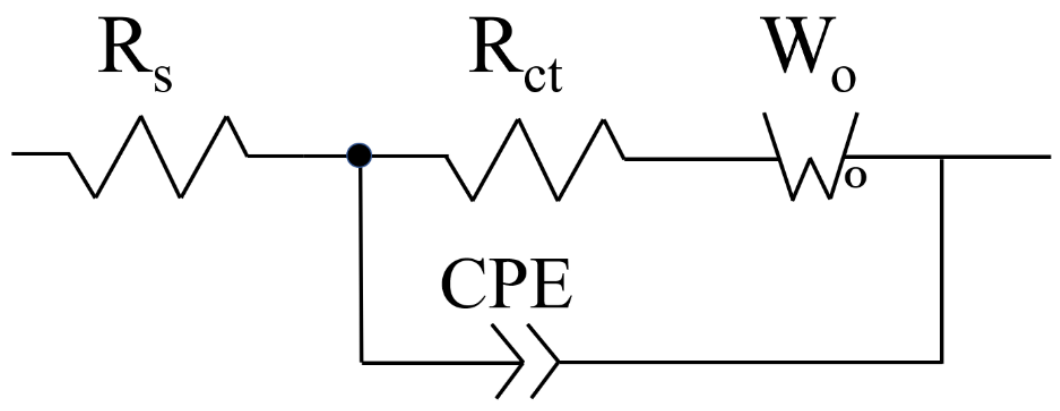

Figure S8. Equivalent circuit diagram of EIS impedance spectrum. 
Table S1. EDX data of $\mathrm{Ni}_{0.2} \mathrm{Co}_{0.1} \mathrm{Mn}_{0.7} \mathrm{CO}_{3}$ sample. The amounts of metal cations are normalized by defining $\mathrm{Co}=1$.

\begin{tabular}{llll}
\hline Sample & $\mathrm{Ni}$ & $\mathrm{Co}$ & $\mathrm{Mn}$ \\
\hline $\mathrm{Ni}_{0.2} \mathrm{Co}_{0.1} \mathrm{Mn}_{0.7} \mathrm{CO}_{3}$ & 2.09 & 1 & 7.06 \\
\hline
\end{tabular}

Table S2. Lattice parameters and X-ray Rietveld refined patterns analysis of spinel sample

\begin{tabular}{cccc}
\hline Sample & Lattice parameters(a)/A & Unit cell volume $(\mathrm{V}) / \AA^{3}$ & $\mathrm{I}_{(311)} / \mathrm{I}_{(400)}$ \\
\hline S800 & 8.22 & 555.4 & 0.78 \\
S850 & 8.25 & 561.5 & 0.83 \\
S900 & 8.27 & 565.6 & 1.08 \\
\hline
\end{tabular}

Table S3. Electrochemical performance of spinel samples in the voltage range of $2.0-4.95 \mathrm{~V}$.

\begin{tabular}{ccccc}
\hline Sample & $\begin{array}{c}\text { Charged specific } \\
\text { capacity }\left(\mathrm{mAh} \mathrm{g}^{-1}\right)\end{array}$ & $\begin{array}{c}\text { Discharged } \\
\text { secific capacity } \\
\left(\mathrm{mAh} \mathrm{g}^{-1}\right)\end{array}$ & $\begin{array}{c}\text { Coulomb } \\
\text { efficiency }(\%)\end{array}$ & $\begin{array}{c}35 \text { cycles } \\
\text { capacity } \\
\text { retention } \\
(\%)\end{array}$ \\
\hline S800 & 129.1 & 237.4 & 183.8 & 85.0 \\
S850 & 142.4 & 241.2 & 169.4 & 89.0 \\
S900 & 129.9 & 172.2 & 132.6 & 79.0 \\
\hline
\end{tabular}


Table S4. Electrochemical performance of spinel and S-L samples in the voltage range of $2.0-4.95 \mathrm{~V}$.

\begin{tabular}{ccccc}
\hline Sample & $\begin{array}{c}\text { Charged specific } \\
\text { capacity } \\
\left(\mathrm{mAh} \mathrm{g}^{-1}\right)\end{array}$ & $\begin{array}{c}\text { Discharged } \\
\text { specific capacity } \\
\left(\mathrm{mAh} \mathrm{g}^{-1}\right)\end{array}$ & $\begin{array}{c}\text { Coulomb } \\
\text { efficiency } \\
(\%)\end{array}$ & $\begin{array}{c}50 \text { cycles } \\
\text { capacity } \\
\text { retention } \\
(\%)\end{array}$ \\
\hline S850 & 142.4 & 241.2 & 169.4 & 81.2 \\
S-L-0.05 & 136.1 & 230.0 & 169.0 & 78.4 \\
S-L-0.1 & 124.9 & 171.5 & 137.3 & 117.7 \\
S-L-0.2 & 156.7 & 143.3 & 91.5 & 129.8 \\
S-L-0.3 & 196.4 & 151.3 & 77.0 & 129.8 \\
S-L-0.4 & 290.1 & 226.4 & 78.0 & 109.4 \\
S-L-0.5 & 246.6 & 164.5 & 66.7 & 118.9 \\
\hline
\end{tabular}

Table S5. Impedance data of S sample and S-L-0.4 sample before and after 50 cycles.

\begin{tabular}{llll}
\hline Sample & Rs / ohm & Rct / ohm & $D_{\mathrm{Li}+}\left(\mathrm{cm}^{2} \mathrm{~s}^{-1}\right)$ \\
\hline S & 4.1 & 25.3 & $3.22 \times 10^{-11}$ \\
S-L-0.4 & 5.0 & 46.3 & $2.35 \times 10^{-11}$ \\
S-50cycles & 3.9 & 192.9 & $1.32 \times 10^{-12}$ \\
S-L-0.4-50cycles & 9.3 & 129.4 & $3.32 \times 10^{-12}$ \\
\hline
\end{tabular}

